\title{
The return-on-education gap between hispanics and non-hispanic whites
}

\section{La brecha en los rendimientos a la educación entre hispanos y blancos no hispanos en Estados Unidos}

\author{
Gabriela Sánchez-Soto, Andrea Bautista-León \\ y Joachim Singelmann
}

\author{
The University of Texas at San Antonio, Estados Unidos
}

\begin{abstract}
This paper analyzes differences in the return on education between non-Hispanic whites and four groups of Hispanics: Puerto Ricans, Mexicans, Cubans, and other Latin Americans. For Mexicans, Cubans, and other Latin Americans, we also distinguish between native-born in the U.S. and foreign-born immigrants. We use data from the American Community Survey 2008-2013 to estimate the differences in the return on education by comparing income relative to educational attainment across ethnic and immigrant groups. The analyses account for age, education, English skills, citizenship status, union status, year, metro area residence, and region of residence, as well as time spent in the U.S. for the foreign-born. We find that the returns on schooling are lower for Hispanics relative to NH whites, but that there is also a gap in earnings between U.S. and foreignborn Hispanics. The loss of wages experienced by Hispanic immigrants is greater at higher levels of education, and for women.
\end{abstract}

Keywords: Returns on education, earnings differentials, immigrant workers, United States.

\section{Resumen}

Este trabajo analiza las diferencias en los rendimientos a la educación entre blancos no-hispanos y cuatro grupos de hispanos en Estados Unidos (E.U.) puertorriqueños, mexicanos, cubanos, y otros latinoamericanos. Para mexicanos, cubanos, y otros latinoamericanos, también se distingue entre los nacidos dentro y fuera de E.U. Usamos información de la American Community Survey 2008-2013 para estimar las diferencias en los rendimientos a la educación al comparar los ingresos relativos al nivel educativo entre los varios grupos étnicos e inmigrantes. Los análisis toman en cuenta la edad, educación, habilidad con el inglés, si se tiene ciudadanía estadounidense, si se está en unión, año de levantamiento, si se reside en área metropolitana, y región de residencia, además del tiempo que se ha vivido en E.U. para los nacidos fuera del país. Los resultados muestran que los rendimientos a la educación son más bajos para los hispanos comparados con los blancos no-hispanos, pero además hay una brecha de ingresos entre hispanos nacidos dentro y fuera de E.U. La brecha salarial para los migrantes de origen hispano es mayor conforme aumenta el nivel de escolaridad, y para las mujeres en la muestra.

Palabras clave: Rendimientos a la educación, diferencias en ingresos; trabajadores inmigrantes, Estados Unidos. 


\section{INTRODUCTION}

7 here is a long history of research on the cost of being Hispanic for educational and occupational outcomes. Initially, much of that research focused on Mexican-Americans vs. Anglos, with later studies addressing the gap between non-Hispanic (NH) whites and all Hispanics more generally (Poston et al., 1976; Poston and Alvírez, 1973). However, scant attention has been given to immigrants, and rarely has a distinction been made among Hispanics of different national origins. Since there is a well-documented gap in educational achievement by race and ethnicity in the U.S., and immigrants who enter the country often have difficulties joining the labor market at the levels of skill their education would allow in their countries of origin (Sánchez-Soto and Singelmann, 2017), it is important to estimate the influence of ethnicity and immigrant status on the gains from schooling these groups experience relative to nonHispanic whites.

At the individual level, immigrant's human capital characteristics such as education, work experience, and language skills play an important role in the likelihood of obtaining wages commensurate to their schooling (Chiswick and Miller, 2008; Chiswick and Miller, 2009; Dell' Aringa et al., 2015). Further, among immigrants, documentation and citizenships status may also determine whether they are successful in translating education into higher wages (Ikpebe and Seeborg, 2018; Borjas, 2017). In addition, urban residence and regional differences may have an impact on the return on education for immigrant minorities. The purpose of this paper is two-fold: (1) to estimate the return on education for four groups of Hispanics - Puerto Ricans, Mexicans, Cubans, and other Hispanics - in comparison to the return of education for non-Hispanic Whites; and (2) to estimate the return on education for foreign-born Mexicans, Cubans, and other Hispanics and compare it with the return on education for the same native-born Hispanic groups. The present paper renews the discussion of race and ethnic differential in the return on education that had been very intensive during the 1970s and 1980s.

The importance of this research resides in the need for a comparison that identifies differences between U.S. born groups and foreign-born Hispanic immigrants. Immigrants face specific difficulties entering and integrating into the labor market in the destination countries (Sánchez-Soto 
and Singelmann, 2017; Dell' Aringa et al., 2015). These difficulties include specific barriers to employment in the U.S. that are related to an inability on the part of migrants to translate their education in the place of origin into an appropriate occupation to gain commensurate earnings. Because of these difficulties, many immigrants obtain employment in areas unrelated to their previous experience or skills, and in occupations with lower pay than natives with similar human capital.

Another important issue is the need to account for heterogeneity within Hispanic groups. Latin American countries have different histories of migration to the United States, and the profile of the immigrant populations from these specific countries are very diverse. Some of the variation is related to the educational and socioeconomic make up of these immigrant groups, and to the probability that these immigrants are undocumented. By comparing immigrants not only across nativity status, but also across major national groups, we are able to estimate disparities in earnings, net of the heterogeneity within the Hispanic ethnic category.

\section{Previous research}

Previous research has found a consistent income gap between $\mathrm{NH}$ whites and Hispanics or Mexican Americans that is net of education, labor income, occupation, labor supply and other controls (Cotton, 1985; Poston and Alvírez, 1973; Poston et al., 1976). In the early 1970s, several researchers examined the extent to which difference in income between (then) Anglo and could be explained by differentials in human capital and occupational status. For example, Poston and Alvarez found that even when human capital and other economic factors were controlled for, the income differential between Anglos and Mexican American workers persisted. They labeled this the cost of being Mexican American. Further investigation (Poston et al., 1976) showed that despite the rise of the Chicano movement during the late 1960s, Mexican Americans did not gain in income vis-àvis non-Hispanic white even when education was controlled for. In fact, both young and older workers experienced a decrease in the relative return on education or, in other words, an increase in the cost of being Mexican American from 1960 to 1970 . Related research showed that the Hispanic earnings gap relative to non-Hispanic whites is particularly large in highstatus occupations (Takei, 2005). Neidert and Tienda (1984) showed the importance of college credentials for male Mexicans and Central/South American immigrants, but they, too, found that the return on education, especially for Puerto Rican and Mexican men, was substantially lower 
than that for non-Hispanic whites. Further, Neidert and Farley's (1985) analysis of the 1979 Current Population Survey showed that the significantly lower return on education for Mexican immigrants, when compared to non-Hispanic whites, persisted in the second and third generation. Earnings differences are also much larger for minority females than for males (Durden and Gaynor, 1998). In addition, self-employed Hispanics have greater earnings than employed Hispanics (Olson et al., 2000). Finally, the lower return on education for native-born Hispanics, especially Mexicans, in comparison to non-Hispanic whites, has also been reported for African Americans (Cotton 1985; Johnson and Sell, 1976).

An interesting finding regarding the return on education was provided by Telles and Murgia (1990) who showed that income differences among Mexicans, controlled for socioeconomic factors, were partly the result of phenotypic discrimination: darker-skinned Mexican Americans earned less than those with lighter skin. Although some research called this finding into question (Bohara and Davila 1992), Telles and Murgia (1992) were able to show the validity of their findings. While the present paper cannot incorporate phenotype into the analysis, Telles and Murgia's findings should be kept in mind when we discuss our findings.

More recent research confirms earnings disparities and precarious work conditions for immigrants from Latin America remain. In terms of earnings, these disparities have increased over time, particularly those who are undocumented (Massey et al., 2016). Evidence also supports that the work and earnings conditions of immigrants have changed significantly over time due to specific economic and political moments. With the increase in immigration enforcement in the last couple of decades it is likely that benefits from migration may have declined for some groups (Gentsch and Massey, 2011), especially those more likely to be perceived as undocumented migrants. For many others, immigrant earnings depend on citizenship status, language ability, time spent in the U.S., and country of origin (Ikpebe and Seeborg, 2018; Massey et al., 2016; Gill and Ahmad, 2018). More specifically, although Mexican immigrants were more likely to remain continuously employed during the Great Recession, they were more likely to experience involuntarily part-time employment, thus reducing the returns to their work (Sisk and Donato, 2016).

Previous research has found that immigrants are likely to experience no returns to their work experience prior to migration, and overall, human capital acquired in the place of origin is less likely to transfer to the place of destination (Ferrer and Riddell, 2008; Dell'Aringa et al., 2015; Perry, 
2017). However, the transferability of human capital is also dependent on the cultural proximity between the country of origin and destination. For instance, immigrants from the U.K. and the U.S. in Canada receive similar returns to schooling than Canadians, whereas immigrants from other regions experience lower returns to schooling (Ferrer and Riddell, 2008; Kaushal et al., 2016). Similarly, in Spain, Latin American immigrants and in Spain experience higher returns on education (Sanromá et al., 2015). In the U.S., the difference in earnings is greater for black and Hispanic immigrants relative to natives than for white and Asian immigrants (Villarreal and Tamborini, 2018); a similar effect is observed in the U.K. where ethnic minorities, particularly blacks, Pakistanis, and Bangladeshis, experience higher risks of unemployment and lower earnings compared to other groups (Li and Heath, 2018).

In terms of gaining experience in the local labor market, research has found that the more time immigrants spend in the country of destination, earnings would tend to converge with those of natives, though in many cases, this effect is confined to more educated immigrants (Ikpebe and Seeborg, 2018; Dell'Aringa et al., 2015; Sanroma et al., 2015). However, even when earnings approach convergence, a gap remains and the rate at which immigrants earnings increase is lower than that for natives (Decudesl, 2005). Although the labor market integration of immigrants varies overtime, in some countries being an immigrant is related to fewer job changes and limited occupational mobility after the first job in the destination country (Brenzel and Reichelt, 2017; Sánchez-Soto and Singelmann, 2017). Other research finds that, regardless of the time spent in the labor market, nativity and citizenship status remain important determinants. For instance, research finds that compared to foreign born Latinas, native born Latina workers receive greater returns to schooling and previous work experience (Mattos, 2018; Sanroma et al., 2015)

Another important consideration is the educational composition and selectivity of immigrants. Although Mexican and Central American immigrants are thought to be negatively selected in terms of education (Borjas, 1987; Feliciano, 2005), recent research finds that, relative to those working in the same occupation, Mexican migrants are positively selected within their occupation (Villarreal, 2016). This is consistent with previous expectations of occupational mismatch among immigrants, whereby foreign workers often end up in jobs for which they are over-prepared (SánchezSoto and Singelmann, 2017; Villarreal and Tamborini, 2018; Sanroma et al., 2015). Besides the educational selectivity of immigrants, gender in- 
equality patterns in the labor market of the home country also influence the educational selectivity of female immigrants (Huh, 2017; Hoover and Yaya, 2010). Furthermore, immigrant women are more likely to have lower earnings relative to men (Cobas-Valdés et al., 2016), we expect that overall, men will outearn women, especially the foreign born.

\section{DATA AND METHODS}

From the Integrated Public Use Micro Data Series (IPUMS-USA) of the American Community Survey (ACS) 2008-2013, we selected data for native-born non-Hispanic $(\mathrm{NH})$ whites and Hispanic respondents between the ages of 16 and 65, resulting in a sample of 6'887,592 individuals; of these 49.8 per cent are males. To identify the returns on education, we estimate Ordinary Least Squares regression models predicting the wages of foreignborn and U.S.-born Hispanics compared to NH whites given different levels of education. These models are as follows:

\section{Dependent variable}

Income. We use the natural logarithm of the total pre-tax wage and salary income received by the respondents during the previous twelve months. Sources of income include wages, salaries, commissions, cash bonuses and other money income received from an employer.

\section{Independent variables}

Education measure. Our main objective is to estimate the returns on education as expressed by the wages individuals earn at every level of schooling, controlling for other characteristics. Education is also a measure of how qualifications contribute to the earnings of Hispanics. We use a categorical measure of education: less than high school, high school completed, and more than high school education (see also Neidert and Tienda, 1984).

Ethnicity and nativity measures. For our analysis, we select two main groups: NH whites and Hispanics. NH whites include only U.S.-born respondents, while the Hispanic group includes both foreign-born and U.S.born respondents. To estimate differences among Hispanic groups, we split the Hispanic sample into four categories according to national origin: Mexicans, Cubans, Puerto Ricans and other Hispanic; these groups are further stratified by foreign-born (FB) and native-born (NB) in our analyses.

Other independent variables. Our analysis accounts for various human capital and context characteristics such as age, English language skills, 
whether the respondent is in a cohabiting or marital union, citizenship status, year of survey, living in a metropolitan area, and region of residence. Separate analyses are estimated for men and women. We measure age in years and we use it to account for human capital accumulation over the life course, since older workers are more likely to have spent more years in the labor market and accumulated more experience and skills that may provide them with better wages than younger workers. The language skills indicator classifies respondents into two categories according to their level of mastery of English: i) does not speak English, or does not speak it very well and ii) speaks English well to speaks only English. We account for U.S. citizenship with the measure that indicates if the respondent is a U.S.born citizen, a naturalized citizen, or a non-citizen. Unfortunately, the data does not allow to account for immigrant documentation status.

Since we use records from the 2008 to 2013 ACS, we include a dummy variable that controls for the year to which each observation belongs. The year indicator will also allow us to control for potential influences of the specific economic context in each year, for instance whether the Great Recession or the post-Great Recession periods had any identifiable impacts on the wages of workers. To account for labor markets and the availability of jobs, we use a dummy variable that equals one if the household is located within a metropolitan area, and a categorical measure of region of residence which indicates residence in the Northeast, Midwest, South, and West.

Methods. We estimate OLS regressions to assess the determinants of wages (logged) and compare the different ethnic and nativity groups. We compare NH whites to both foreign-born and U.S.-born Hispanics by nationality group. All models are stratified by sex to compare the differences in the determinants of wages for men and women. We estimate a baseline model with only the indicators for ethnicity/nationality and foreign-born status. A second model adds the covariates of interest.

These models will help us test our hypotheses that net of human capital characteristics, Hispanics will have disproportionately lower wages than $\mathrm{NH}$ whites, and that this gap in wages is wider for foreign-born Hispanics. Some would argue that some of the wage differentials between immigrants and natives could be explained by the fact that migrants are highly selected from the population of the country of origin and would tend to be younger and less educated than the native populations; thus, any gap in salary we observed should be explained away if we account for selectivity. Another concern could be that the differences between NH whites and Hispanics 
derive from the differences in composition of the labor force, due to a process of selectivity into being a worker. In order to test the robustness of our results, we replicate our analysis using a two-step Heckman selection model that accounts for the educational and age distribution of the groups in the sample. This model consists of a two-step estimating procedure, in the first step we estimate the probability of a respondent to be in the U.S. labor force given their age and education; in step two we estimate the full model by adding a variable that is derived from the first equation estimate, which helps us estimate wage differentials across groups accounting selectivity into paid employment. There are not significant differences in the results of the Heckman selection model when compared with the results from the OLS regression results. Additionally, the selection coefficient in the Heckman model is not statistically different to zero, which means there is no evidence of sample selection and the OLS results are consistent. Results from the preliminary analysis are available upon request.

Table 1 shows weighted descriptive characteristics of our sample by sex, with the ethnic categories presented by nativity status. The largest group among Hispanics are Mexicans; for males the percentage of foreign born is larger than that for native born. Only two per cent of our sample are Puerto Rican, all of whom are U.S. citizens by birth. For Cubans, both more males and females are foreign born than are native born. The same applied of the category Other Hispanic.

Regarding educational attainment of the entire sample, more than one half has an education beyond high school, and about one quarter has higher education. English language skills are an important determinant of the type of jobs immigrants can obtain. Overall, about five per cent of the sample speak no English or speak it only poorly. Finally, slightly over 80 percent of the entire sample of workers live in metropolitan areas. Their distribution across the regions of the country shows that around 19 per cent live in the Northeast, about 21 per cent in the Midwest, over 35 per cent in the south, and around 25 per cent in the West.

Table 2 presents weighted sample descriptives by nativity and ethnicity status. First, the data show that the native-born (NB) groups have higher levels of education, both for the proportion who completed high school and those with post-secondary education. Foreign-born (FB) Mexicans are the least educated of the group, followed by the FB-Other Hispanic. Most natives speak English very well, two thirds of Cuban or Other Hispanic speak English well, while FB Mexicans are evenly split in half. Rates of citizenship status among the foreign born also vary. 
The return-on-education gap between hispanics and non-hispanic whites /G. SÁNCHEZ-SOTO et al.

Table 1: Demographic characteristics of the sample, by sex, 2008-2013

\begin{tabular}{|c|c|c|}
\hline & Men $(\%)$ & Women $(\%)$ \\
\hline \multicolumn{3}{|l|}{ Ethnic group by nativity } \\
\hline \multicolumn{3}{|l|}{ U.S. Born } \\
\hline Non-Hispanic White & 78.61 & 80.17 \\
\hline Puerto Rican & 2.02 & 2.06 \\
\hline Mexican & 6.57 & 6.36 \\
\hline Cuban & 0.29 & 0.29 \\
\hline Other Hispanic & 1.63 & 1.58 \\
\hline \multicolumn{3}{|l|}{ Foreign Born } \\
\hline Mexicans & 6.94 & 5.76 \\
\hline Cubans & 0.49 & 0.48 \\
\hline Other Hispanic & 3.45 & 3.31 \\
\hline \multicolumn{3}{|l|}{ Educational attainment } \\
\hline Less than High School & 18.5 & 15.05 \\
\hline High School & 57.12 & 57.52 \\
\hline Post-Secondary & 24.38 & 27.43 \\
\hline \multicolumn{3}{|l|}{ English Skills } \\
\hline Does not speak/does not speak well & 5.18 & 4.98 \\
\hline Speaks well /speaks only English & 94.82 & 95.02 \\
\hline \multicolumn{3}{|l|}{ Region of Residence } \\
\hline Northeast & 18.82 & 19.18 \\
\hline Midwest & 20.61 & 20.77 \\
\hline South & 35.12 & 35.87 \\
\hline West & 25.45 & 24.18 \\
\hline $\mathrm{N}$ & 3’330,909 & 3’278,291 \\
\hline
\end{tabular}




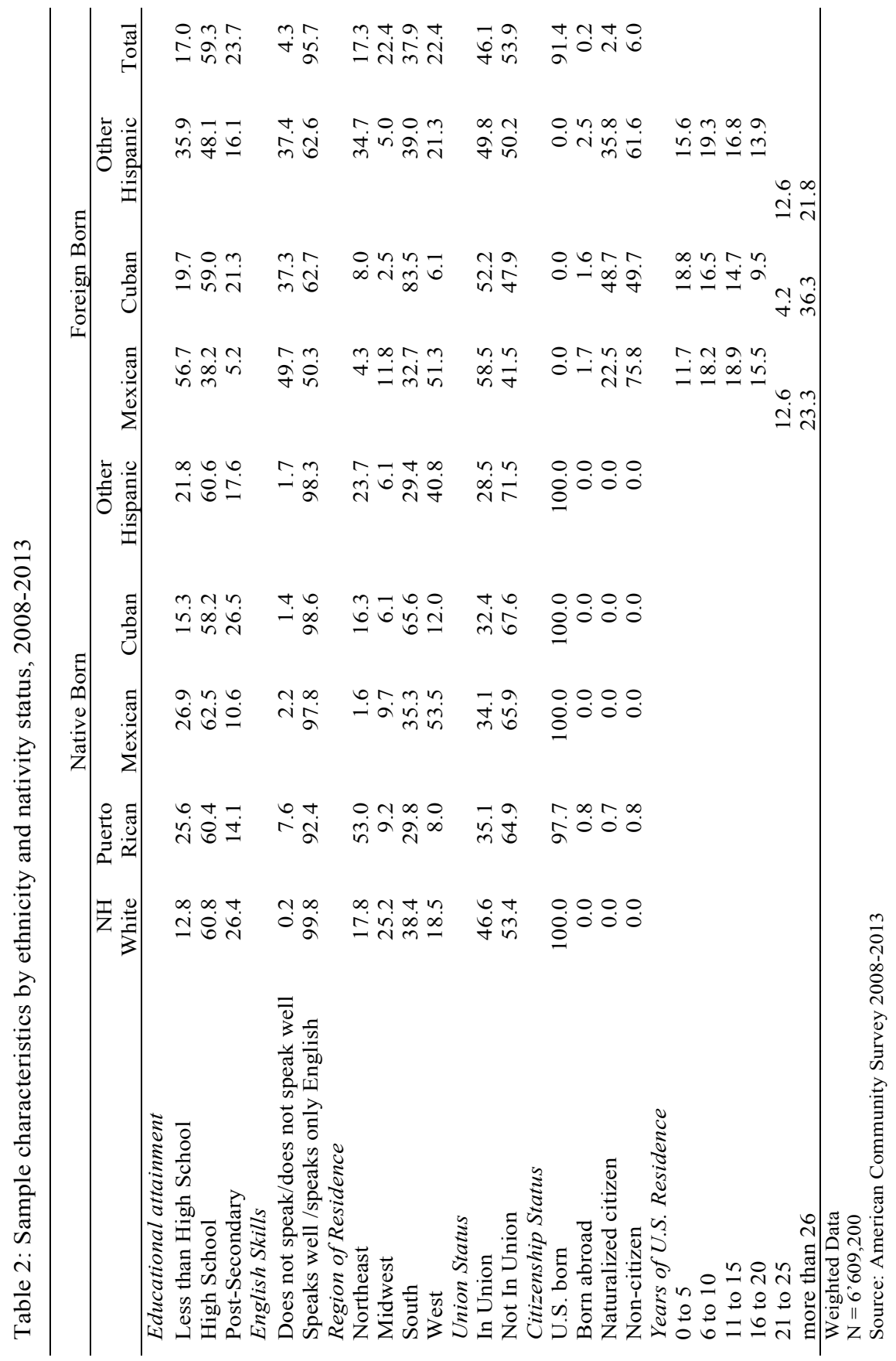


While most FB Mexicans are not U.S. citizens, about half of $\mathrm{FB} \mathrm{Cu}$ bans are naturalized and almost two-thirds of the FB Other Hispanic group are. The number of years spent in the U.S. by the FB are distributed quite evenly, except for a higher concentration in the category for more than 26 years; Table 2 shows that 23 per cent, 36 per cent and 22 per cent of Mexicans, Cubans and Other Hispanics, respectively, have been in the U.S. for a significant amount of time.

\section{Multivariate analysis Results}

We present our findings separately for males and females. For both, we estimated two models: a baseline model focusing only on nativity and ethnicity status, and a model that adds our independent variables. Table 3 presents the two models for men. The baseline model shows that all Hispanic groups earn less than do non-Hispanic whites, with Mexicans and other Hispanics experiencing far lower earnings when compared to $\mathrm{NH}$ whites than is the case for Cubans. This difference is undoubtedly the result of the special conditions for Cuban Immigration to the United States which included a large proportion of middle-class immigrants, especially in the early years after the Cuban revolution (Pérez, 1986a; Portes and Bach, 1980; Pérez, 1986b). Surprisingly gap with NH white males is greater for native-born Hispanics than for those who immigrated.

When the other independent variables are included in Model 2, these difference reverse for NB Mexican and NB Cuban males: in comparison to the earnings of $\mathrm{NH}$ white males, their earnings are higher, though the effect has greater magnitude for NB Cubans. For the FB, the negative trend only reverses for Mexicans and Other Hispanics. There is essentially no earnings differential for Puerto Ricans. Both FB other Hispanics and, especially, FB Mexicans do better vis-à-vis NB whites than to their NB counterparts.

As expected, age has a positive effect on earnings. Similarly, as we had anticipated, earnings increase substantially with greater educational attainment, especially for those with post-secondary education. Speaking English well also has a positive effect on earnings. Men in a union earn a more than men not in union. Contrary to expectations, citizenship status does not have a significant effect on men's earnings; however, it is possible that documentation status — which we cannot account for- is the real source of disadvantage for immigrants. 
Table 3: Estimates from OLS regression models to estimate log earnings for males, 2008-2013

\begin{tabular}{|c|c|c|c|c|c|c|}
\hline & \multicolumn{3}{|c|}{ Model 1 -Baseline } & \multicolumn{3}{|c|}{ Model 2- full model } \\
\hline & $\beta$ & Std. Err. & $P>|t|$ & $\beta$ & Std. Err. & $\mathrm{P}>|\mathrm{t}|$ \\
\hline \multicolumn{7}{|l|}{ Native Born } \\
\hline \multicolumn{7}{|l|}{ NH White (ref.) } \\
\hline Puerto Rican & -0.280 & 0.006 & $*$ & -0.006 & 0.005 & \\
\hline Mexican & -0.411 & 0.003 & $*$ & 0.005 & 0.003 & $* * *$ \\
\hline Cuban & -0.189 & 0.014 & $* *$ & 0.061 & 0.012 & $*$ \\
\hline Other Hispanic & -0.442 & 0.006 & $*$ & -0.059 & 0.005 & $*$ \\
\hline \multicolumn{7}{|l|}{ Foreign-Born } \\
\hline Mexican & -0.324 & 0.003 & $*$ & 0.141 & 0.028 & $*$ \\
\hline Cuban & -0.023 & 0.011 & * & -0.130 & 0.029 & $*$ \\
\hline Other Hispanic & -0.187 & 0.004 & $*$ & 0.067 & 0.028 & $* *$ \\
\hline Age & & & & 0.027 & 0.000 & $*$ \\
\hline \multicolumn{7}{|l|}{ Educational attainment } \\
\hline \multicolumn{7}{|l|}{ Less than High School (ref.) } \\
\hline High School & & & & 0.651 & 0.002 & * \\
\hline Post-Secondary & & & & 1.320 & 0.002 & * \\
\hline \multicolumn{7}{|l|}{ English Skills } \\
\hline \multicolumn{7}{|c|}{ Does not speak/does not speak well (ref.) } \\
\hline Speaks well /speaks only English & & & & 0.074 & 0.004 & $*$ \\
\hline \multicolumn{7}{|l|}{ Union Status } \\
\hline \multicolumn{7}{|l|}{ In Union (ref.) } \\
\hline Not In Union & & & & 0.623 & 0.001 & $*$ \\
\hline \multicolumn{7}{|l|}{ Citizenship Status } \\
\hline \multicolumn{7}{|l|}{ U.S. born (ref.) } \\
\hline Born abroad & & & & -0.030 & 0.029 & \\
\hline Naturalized citizen & & & & -0.008 & 0.028 & \\
\hline Non-citizen & & & & 0.042 & 0.028 & \\
\hline \multicolumn{7}{|l|}{ Urban Residence } \\
\hline \multicolumn{7}{|l|}{ Metro (ref.) } \\
\hline Non-Metro & & & & 0.152 & 0.002 & * \\
\hline \multicolumn{7}{|l|}{ Region of Residence } \\
\hline \multicolumn{7}{|l|}{ Northeast (ref.) } \\
\hline Midwest & & & & -0.084 & 0.002 & $*$ \\
\hline South & & & & -0.035 & 0.002 & $*$ \\
\hline West & & & & 0.004 & 0.002 & $* *$ \\
\hline \multicolumn{7}{|l|}{ Year } \\
\hline \multicolumn{7}{|l|}{2008 (ref.) } \\
\hline 2009 & & & & -0.031 & 0.002 & $*$ \\
\hline 2010 & & & & -0.060 & 0.002 & $*$ \\
\hline 2011 & & & & -0.090 & 0.002 & $*$ \\
\hline 2012 & & & & -0.063 & 0.002 & $*$ \\
\hline 2013 & & & & -0.039 & 0.002 & $*$ \\
\hline
\end{tabular}

Weighted Data

$\mathrm{N}=3$ '330,909

$* \mathrm{P}>0.05 * * \mathrm{P}>0.01$

Source: American Community Survey 2008-2013 
Males in metro areas have higher earnings than those living in non-metro areas. Compared to those living in the Northeast, Midwest and South residents have lower earnings, and those in the West have higher wages, on average. Finally, the year of the information matters: as the Great Recession unfolds, earnings decreased after 2008.

In Table 4, we present the results of our two models for females. The baseline model for females shows that all groups, except for FB Cubans, earn less than $\mathrm{NH}$ whites. However, the relative income differences between Hispanic females and $\mathrm{NH}$ white females are smaller than what we found for males (see Table 3). A similar finding has been found for female black-white differences and related to the lower earnings of females in general (e.g., Blau and Beller 1992). The most disadvantaged in terms of earnings are Mexican women, both FB and NB, the same as we found for males. In contrast to our findings for males, FB Hispanic females tend to do less well vis-à-vis NH white females tan do their NB counterparts, with the exception of Cuban females.

Once we include the independent variables in Model 2, the trends completely reverse, and FB Cuban women are the only ones with lower earnings when compared to $\mathrm{NH}$ white females.

As in the case of males, age, educational attainment, language skill, union status, and metro residence had positive effects on earnings. Naturalized citizen women have higher earnings than U.S. born citizens. Regional differences follow the same trend for women than form men. And similarly to males, earnings of females were lower after the start of the Great Recession.

The findings for both males and females show that for most Hispanic groups, their lower earnings vis-à-vis $\mathrm{NH}$ whites can be explained by a number of characteristics: when those factors are included in the equations, most Hispanic groups no longer earn less than their NH white counterparts.

To better understand the gaps in the returns on education by nativity/ ethnicity group, Figures 1 and 2 show the predicted mean earnings for men and women, respectively. Our predicted values hold other characteristics constant and are estimated by nativity, ethnicity, and educational level. First, in Figure 1 for men, we see that at the educational level of less than High School, all Hispanics except Cubans have higher earnings than $\mathrm{NH}$ whites, when other factors are controlled for. FB Mexicans and FB Other Hispanics receive an especially high return on this level of education. 
Table 4: Estimates from OLS regression models to estimate log earnings for females, 2008-2013

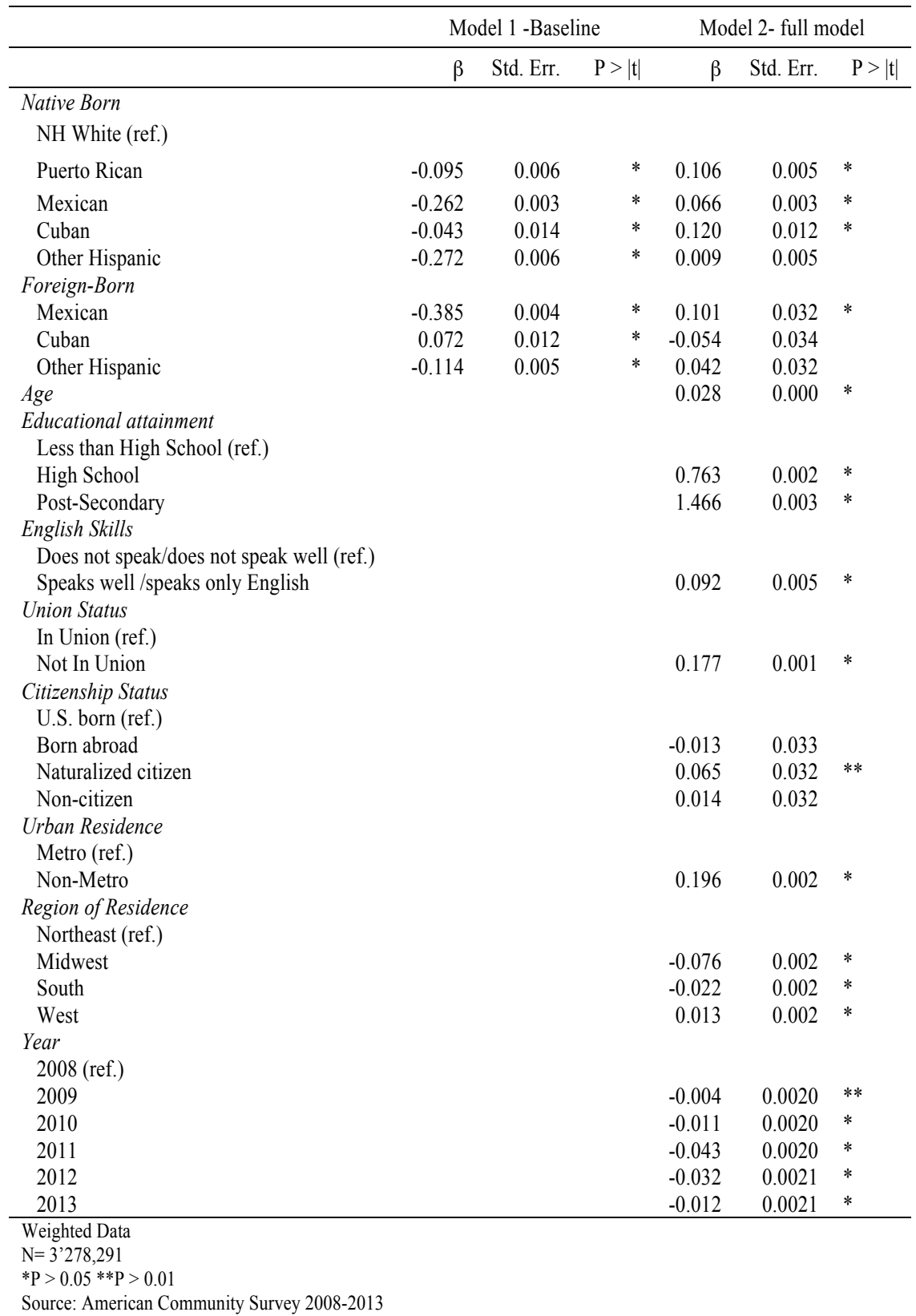


Figure 1: Predicted earnings, by nativity and ethnicity status for men, 2008-2013

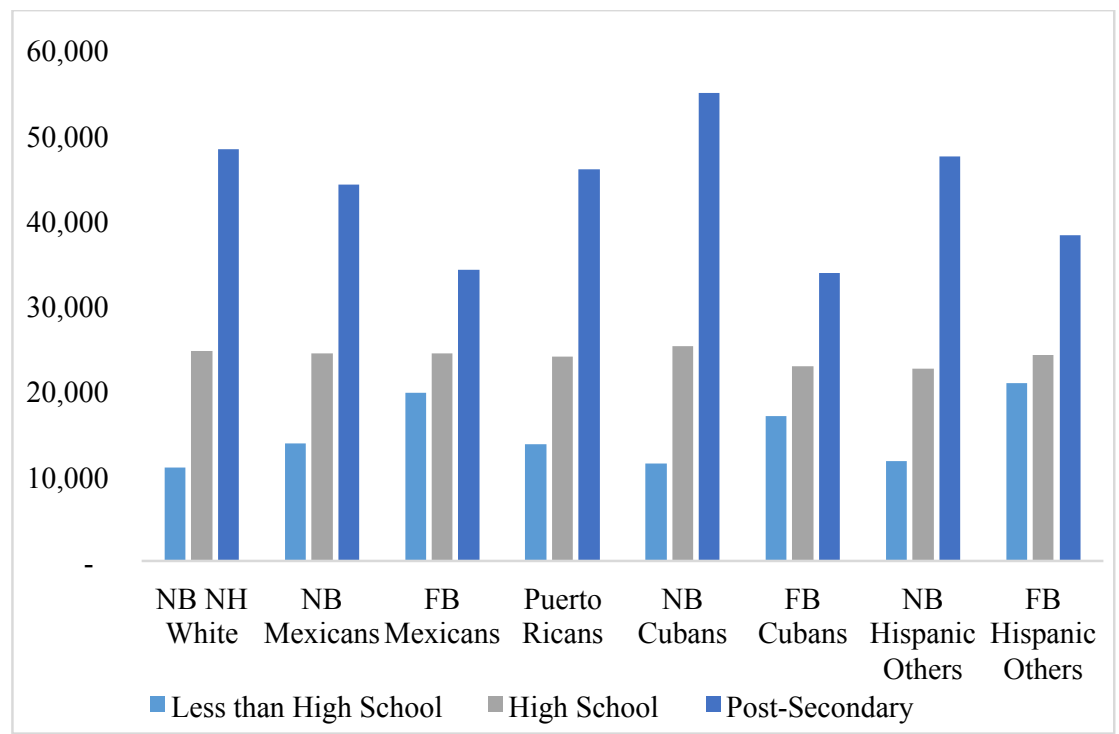

Source: American Community Survey 2008-2013.

Figure 2: Predicted earnings, by nativity and ethnicity status, for women 2008-2013

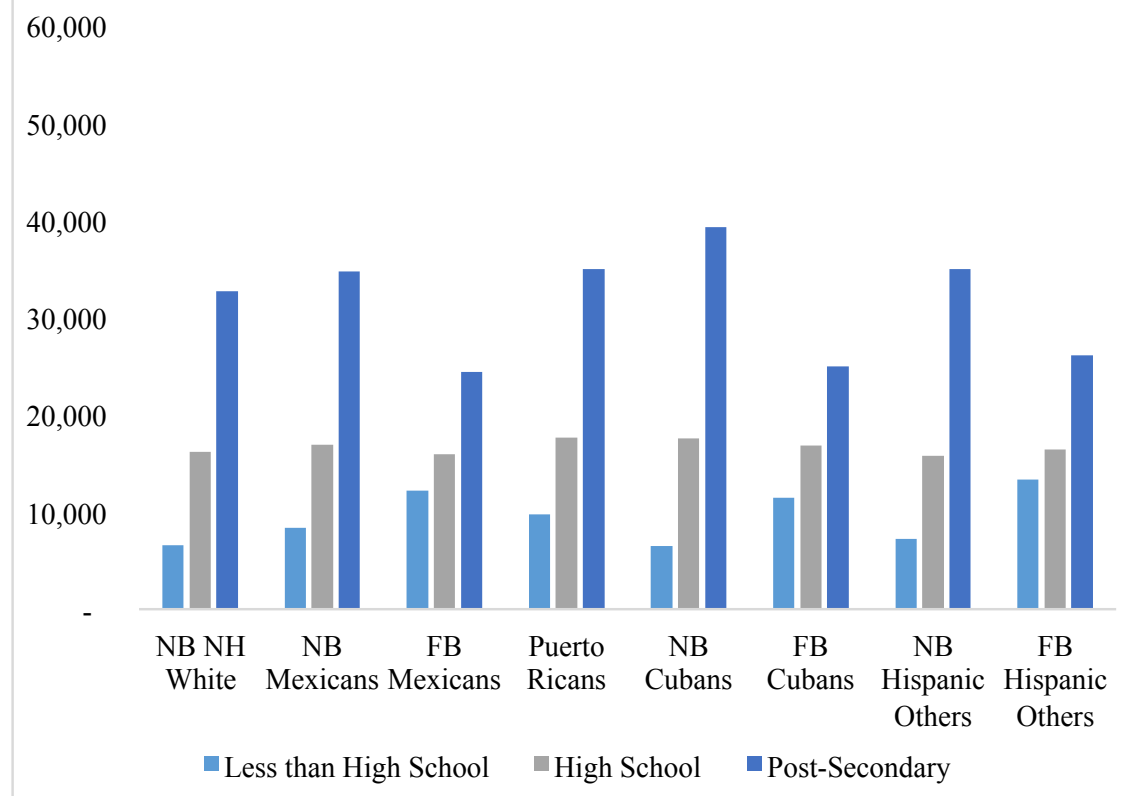

Source: American Community Survey 2008-2013. 
There is very little variation in the return on education among all ethnic groups with High School completion. Among males with post-secondary education, the variation in income again increases substantially: $\mathrm{NB} \mathrm{Cu}-$ bans and $\mathrm{NH}$ whites receive the highest return on higher education, with FB Mexican and FB Cubans receiving the lowest return. Thus, the outcome for FB Mexicans is reversed: while they received the highest return on less than High School education, they receive the second lowest return for males with post-secondary education, barely outranking FB Cubans. In general, for all Hispanic groups, those who are native born receive a higher return on post-secondary education than those who are foreign born.

Figure 2 shows the predicted earnings for women. Overall, women's earnings are much lower than men's. For all ethnic groups, predicted earnings increase substantially with additional education, with the most educated having the highest earnings by far. Some gaps are especially large, for instance for NB Cubans, NB Mexicans, and NB Other Hispanics. The groups who benefit from education the least are FB Mexicans and $\mathrm{FB} \mathrm{Cu}-$ bans; while those two groups are also the ones where low education results in higher wages compared to other ethnic groups, their return high education is the lowest. Another noteworthy finding presented in Figure 2 is the fact the NB Cuban females have the lowest return on education if they have less than high school, but their return on education is the highest if they have post-secondary education.

In addition to the main OLS models, we tested an additional set of models to estimate whether there is an effect of the time spent in the U.S. on the earnings of foreign born Hispanics. Specifically, we would like to know whether the time spent residing in the U.S. is associated to earnings, and whether this effect is the same across Hispanic groups. In order to test this expectation, we select the foreign born in our sample and using the same specification as in Model 2 in Tables 3 and 4, we test for an interaction between national origin and time of residence in the U.S. Time spent in the U.S. is measured using categorical indicator that groups years into 5-year intervals up to 25 years, a last category is added for those who have spent 26 years or more in the U.S. Figures 3 and 4 present the estimated log odds (ßs) of the interaction effect for each national group by number of years in the U.S., for males and females respectively. The graphs only show statistically significant effects and the category of reference is foreign born Mexicans who have been in the U.S. for 5 years or less. 
In Figure 3, the results for Mexican and other Hispanic men show that after five years in the U.S., the rate of increase in earnings remains constant across time. In the case of Cuban men, the effects are significant only after 11 years spent in the U.S., though after this, every additional five years spent in the U.S. are associated to significant growth in earnings greater than that of other groups. For Puerto Ricans, only some duration periods were significant, but overall, there are significant increases in log earnings for Puerto Ricans who have been in the U.S. for over 10 years and over 25 years.

Figure 3: Estimated Interaction Effect between National Origin and Years Spent in the U.S., for Males, 2008-2013

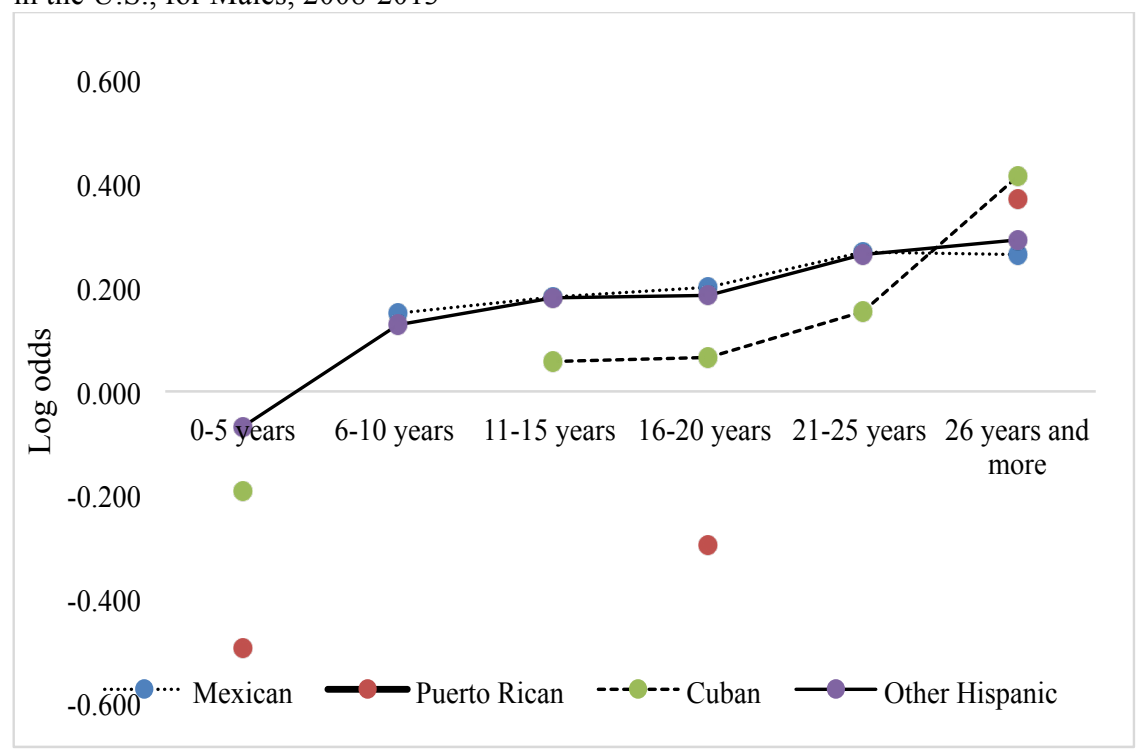

Source: American Community Survey 2008-2013.

The interaction effects are similar for women (Figure 4) although the increases over time are more sharp than for men. Mexican women receive the smallest increases in earnings with more experience in the U.S., while Cuban women greatly benefit from spending more time in the U.S. labor market. The effects for women are of greater magnitude than the effects for men. Just like for men, the only significant effects for Puerto Rican women concentrated at the beginning and the end of the duration distribution. Overall, the interaction models help us see that the length time spent in the U.S. is associated with a reduction in the earnings gap for most of the Hispanic groups. However, Mexican and other Hispanics do not seem to make great 
gains in earnings as they spend more time in the U.S. which may be related to the low returns on education we documented in the results from our fullsample OLS models.

Figure 4: Estimated interaction effect between national origin and years spent in the U.S., for females, 2008-2013

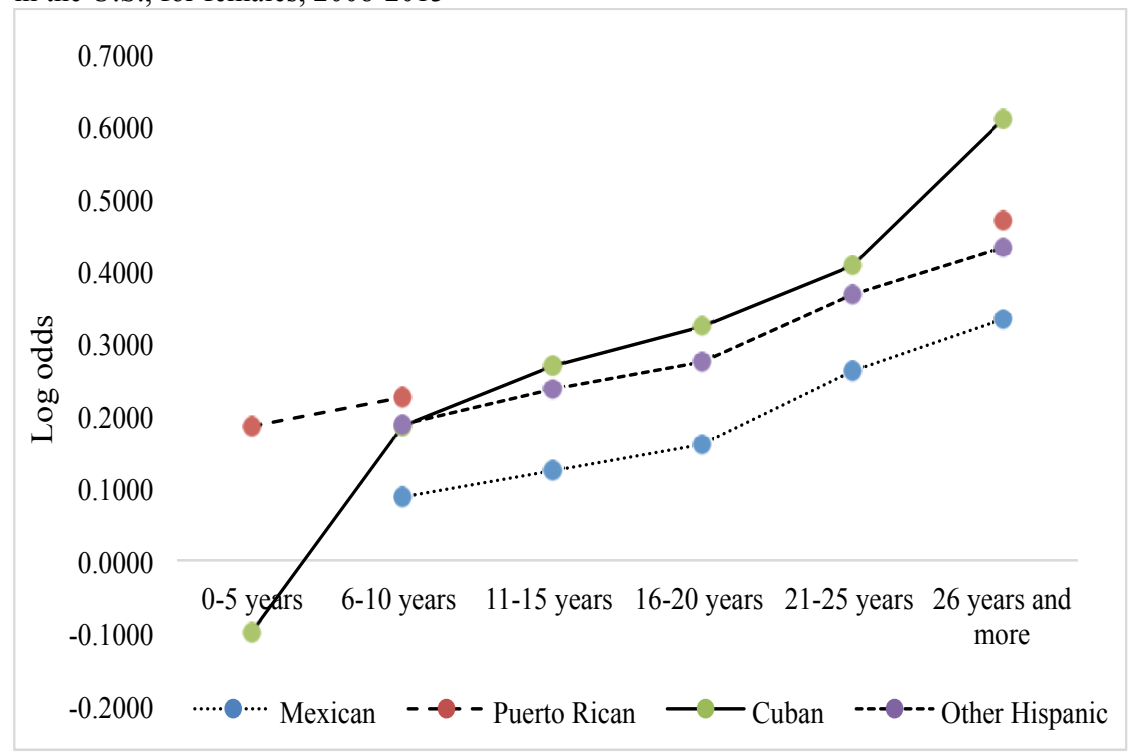

Source: American Community Survey 2008-2013.

\section{Discussion}

In our preliminary analyses, we used a Heckman selection model to estimate whether differences in earnings between FB and NB groups and between Hispanics and $\mathrm{NH}$ whites are a result of selectivity into employment. We find that differences in wages are not due to composition or selectivity of workers, as results from our selection model were not different from the OLS models we present in this paper.

Our analyses show two major result: (1) While it appears that Hispanics, more so males than females, earn less than NH whites, those findings are the results of characteristics related to income rather than a penalty for being Hispanic. Once we control for those characteristics, Hispanics earn slightly more money than $\mathrm{NH}$ whites.

We show that age, human capital, metro and Northeast residence are all positively related to increased income for both sexes. Our findings further show the negative effects of wages of the post-Great Recession period. 
Though our results indicate some recovery over the years, wages in all other years are still lower than in 2008. There are certainly benefits of being a U.S. citizen; this is visible in the positive impacts of education for NB Puerto Ricans and Cubans, and though the additional improvement through naturalization is only significant for Cuban women.

Some of the reasons for lower wages for women are their higher representation in part-time employment and the higher likelihood that they face interruptions in employment due to maternity and family-related reasons. Gender inequality in access to better job opportunities may also be at play.

Hispanics, both native born and foreign born, are less likely to score high in characteristics that lead to higher earnings (e.g. education, language ability). Policies aimed at improving the prevalence of those characteristics among Hispanics should lead to more similar earnings between $\mathrm{NH}$ whites and the various groups of Hispanics examined in the present analysis, (2) however, we do find consistent and significant differences in wages by ethnicity and by education. The loss of wages experienced is greater at higher levels of education and for the foreign born, and gaps are particularly wide for women. Overall, Hispanic women's wages are lower, but their predicted earnings do not gain from higher education as much as the wages of $\mathrm{NH}$ white women or men.

Another result indicates that Mexican and Puerto Rican females have the greatest returns to low education, which is perhaps due to increased migrant networks and ethnic occupational niches. However, it is also FB Mexicans who have the lowest return on higher education. This is consistent with our previous work, were we found that highly educated Mexicans were unlikely to enter an occupation in the U.S. of similar status than the occupation they had in Mexico (Sánchez-Soto and Singelmann, 2017). Consistent with previous research, we find that not all foreign born Hispanic groups benefit equally from increased experience in the U.S. labor market. Spending more time in the U.S. translates to higher earnings for FB Cubans, but Mexicans and other Hispanics do not see their earnings increase as they spend more time in the country of destination (Decudesl, 2005).

This second major finding, i.e. Hispanics experience a lower return on higher education than do $\mathrm{NH}$ whites, in some ways qualifies what we said above, namely designing programs that would make the characteristics of Hispanics more similar to those of $\mathrm{NH}$ whites (such as education and language skills), would close the NH white-Hispanic income gap. The lower return on post-graduate education for Hispanics not only gives them fewer 
incentives to obtain higher education, it also increases the relative cost of that education since Hispanics have a harder time to recoup their educational costs with their lower wages. In this sense, our second major finding does point to a cost of being Hispanic. Thus, even if Hispanics achieved the same educational attainment than $\mathrm{NH}$ whites, their income would lag behind. In that sense, a policy program aimed at increasing educational attainment among Hispanics would need to be accompanied by the elimination of barriers into employment (which are often a form of individual and systemic discrimination) in order to be successful.

Though this research unveils important differences in the incorporation of immigrants and Hispanic minorities to the labor market, more work on this area of research is still needed. First, we need to further understand the mechanisms of job placement and wages for immigrants. We also need to be able to account for the effects of previous labor history on immigrants' earnings in the U.S. and the role that social networks may play in placing immigrants in certain jobs or industries. Are immigrants and minorities getting the types of jobs they are trained for? And if they are, are they being paid at the same rate as their native/non-minority counterparts? Overall, it is essential to continue exploring the barriers to labor market integration that Hispanic populations still face in the U.S., with especial interest to the mechanisms that allow for a better recognition of their skills and talents.

\section{REFERENCES}

Blau, F.D. and Beller, A.H., 1992, "Black-white earnings over the 1970s and 1980s: gender differences in trends", in The Review of Economics and Statistics, 74(2), p. 276.

Bohara, A.K. and Davila, A., 1992, "A reassessment of the phenotypic discrimination and income differences among Mexican Americans", in Social Science Quarterly, 73(1), pp. 114-119.

Borjas, G.J., 1987, "Self-Selection and the earnings of immigrants", in American Economic Review, 77(4), pp. 531-53.

Borjas, G.J., 2017, The earnings of undocumented immigrants, Cambridge, MA.

Brenzel, H. and Reichelt, M., 2017, "Job mobility as a new explanation for the immigrant-native wage gap: a longitudinal analysis of the german labor market", in International Migration Review, (Fall), pp. 1-26.

Chiswick, B.R. and Miller, P.W., 2009, "The international transferability of immigrants' human capital", in Economics of Education Review, 28(2), pp. 162-169. 


\section{The return-on-education gap between hispanics and non-hispanic whites /G. SÁNCHEZ-SOTO et al.}

Chiswick, B.R. and Miller, P.W., 2008, "Why is the payoff to schooling smaller for immigrants?", in Labour Economics, 15(6), pp. 1317-1340.

Cobas-Valdés, A., Fernández-Sainz, A. and Wilkinson, S., 2016, “Cuban immigrants in the United States: what determines their earnings distribution?", in Semestre Económico, 19(41), pp. 19-36.

Cotton, J., 1985, “A comparative analysis of black-white and Mexican-AmericanWhite male wage differentials", in The Review of Black Political Economy, 13(4), pp. 51-69.

Decudesl, T., 2005, "Will they ever converge? earnings of immigrant and Canadian-born workers over the last two decades", in International Migration Review, 39(1), pp. 228-258.

Dell'Aringa, C., Lucifora, C. and Pagani, L., 2015, "Earnings differentials between immigrants and natives: the role of occupational attainment", in IZA Journal of Migration, 4(1), pp. 1-18.

Durden, G.C. and Gaynor, P.E., 1998, "More on the cost of being other than white and male", in American Journal of Economics and Sociology, 57(1), pp. 95-103.

Feliciano, C., 2005, "Educational selectivity in U.S. immigration: how do immigrants compare to those left behind?", in Demography, 42(1), pp. 131-152.

Ferrer, A. and Riddell, W.C., 2008, "Education, credentials, and immigrant earnings", in Canadian Journal of Economics, 41(1), pp. 186-216.

Gentsch, K. and Massey, D.S., 2011, "Labor market outcomes for legal mexican immigrants under the new regime of immigration enforcement", in Social Science Quarterly, 92(3), pp. 875-893.

Gill, F. and Ahmad, W., 2018, "The earnings disadvantage of 21st century immigrants in the United States", in The American Economist, pp. 1-14.

Hoover, G.A. and Yaya, M.E., 2010, "Gender differences in income inequality among immigrant populations to the United States", in Social Science Journal, 47(3), pp. 593-608.

Huh, Y., 2017, "Gender empowerment and educational attainment of US immigrants and their home-country counterparts", in Feminist Economics, 23(2), pp. $120-145$.

Ikpebe, E. and Seeborg, M.C., 2018, "Earnings performance of African immigrants: evidence from the American community survey", in Atlantic Economic Journal, 46(2), pp. 215-230.

Johnson, M.P. and Sell, R.R., 1976, "The cost of being black: a 1970 update”, in American Journal of Sociology, 82(1), pp. 183-190.

Kaushal, N. et al., 2016, "Immigrant employment and earnings growth in Canada and the USA: evidence from longitudinal data", in Journal of Population Economics, 29(4), pp.1249-1277. 
Li, Y. and Heath, A.F., 2018, "Persisting disadvantages: a study of labour market dynamics of ethnic unemployment and earnings in the UK (2009-2015)", in Journal of Ethnic and Migration Studies, 0(0), pp. 1-22.

Massey, D.S., Durand, J. and Pren, K.A., 2016, "The precarious position of latino immigrants in the United States", in Donato, K. M. and Massey, D. S. (eds.), The Annals of the American Academy of Political and Social Science, 666(1), pp. 91-109.

Mattos, T., 2018, Foreign Born Latina Earnings and Returns to Education and Experience in the United States, Boston, MA.

Neidert, L.J. and Farley, R., 1985, "Assimilation in the United States: an analysis of ethnic and generation differences in status and achievement", in American Sociological Review, 50(6), p. 840.

Neidert, L.J. and Tienda, M., 1984, "Converting education into earnings: the patterns among Hispanic origin men", in Social Science Research, 13(4), pp. $303-$ 320 .

Olson, P.D., Zuiker, V.S. and Montalto, C.P., 2000, "Self-Employed Hispanics and Hispanic wage earners: differences in earnings", in Hispanic Journal of Behavioral Sciences, 22(1), pp. 114-130.

Pérez, L., 1986a, "Cubans in the United States", in The Annals of the American Academy of Political and Social Science, 487(1), pp. 126-137.

Pérez, L., 1986b, "Immigrant economic adjustment and family organization: the Cuban success story reexamined", in The International Migration Review, 20(1), pp.4-20.

Perry, A., 2017, Are over-qualified immigrants mismatched according to their actual skills? An international comparison of labor market placement in OECD countries, Koln.

Portes, A. and Bach, R.L., 1980, "Immigrant earnings: Cuban and Mexican immigrants in the United States", in International Migration Review, 14(3), pp. $315-341$.

Poston, D.L. and Alvírez, D., 1973, "On the cost of being a Mexican American worker”, in Social Science Quarterly, 53(4), pp. 697-709.

Poston, D.L., Alvirez, D. and Tienda, M., 1976, "Earnings difference between anglo and Mexican American workers in 1960 and 1970: changes in the 'cost' of being Mexican American”, in Social Science Quarterly, 57(3), pp. 618-631.

Sánchez-Soto, G. and Singelmann, J., 2017, “The occupational mobility of Mexican migrants in the United States", in Revista Latinoamericana de Población, 11(20).

Sanroma, E., Ramos, R. and Simon, H., 2015, "How relevant is the origin of human capital for immigrant wages? Evidence from Spain", in Journal of Applied Economics, 18(1), pp. 149-172. 
Sanromá, E., Ramos, R. and Simón, H., 2015, "Portability of human capital and immigrant overeducation in Spain", in Population Research and Policy Review, 34(2), pp. 223-241.

Sisk, B. and Donato, K.M., 2016, "Weathering the storm? The great recession and the employment status transitions of low-skill male immigrant workers in the United States", in International Migration Review.

Takei, I., 2005, Cost of being a Mexican immigrant and being a Mexican noncitizen in California and Texas. Texas AM University.

Telles, E.E. and Murguía, E., 1990, "Phenotypic discrimination and income differences among Mexican Americans", in Social Science Quarterly, 71(4), pp. 682-696.

Telles, E.E. and Murguía, E., 1992, "The Continuing significance of phenotype among Mexican Americans", in Social Science Quarterly, 73(1), pp. 120-122.

Villarreal, A., 2016, "The education-occupation mismatch of international and internal migrants in Mexico, 2005-2012”, in Demography, 53(3), pp. 865-883.

Villarreal, A. and Tamborini, C.R., 2018, “Immigrants' economic assimilation: evidence from longitudinal earnings records", in American Sociological Review, 83(4), pp. 686-715.

\section{RESUMEN CURRICULAR DE LOS AUTORES}

\section{Gabriela Sánchez Soto}

Maestra y Doctora en Sociología por la Universidad de Brown. Ha sido investigadora postdoctoral asociada de la Oficina de Estudios de Población de la Universidad de Princeton (2011-2012). Actualmente es profesora asistente de Demografía en La Universidad de Texas en San Antonio. Entre sus publicaciones recientes destacan, The Occupational Mobility of Mexican Migrants in the United States (en coautoría con Joachim Singelmann), Los determinantes de la ocupación y la movilidad ocupacional de los migrantes latinoamericanos en Estados Unidos, Migration in the Americas (en coautoría con Adriana López Ramírez), y En búsqueda de su camino. Características de los jóvenes que no estudian ni trabajan en la Ciudad de México (en coautoría con Andrea Bautista León)

Dirección electrónica: gabriela.sanchez-soto@utsa.edu

\section{Andrea Bautista León}

Doctora en Demografía Aplicada por la Universidad de Texas en San Antonio, Maestra en Población y Desarrollo por la Facultad Latinoamericana de Ciencias Sociales Sede México y Licenciada en Ciencias Políticas y Ad- 
ministración Pública por la Universidad Nacional Autónoma de México. $\mathrm{Su}$ investigación se especializa en: Transiciones de la escuela al trabajo, Migración de Retorno a México desde Estados Unidos y Demografía y Familia. Actualmente es co-investigadora princiapal del proyecto Migración de Retorno y Derechos Sociales en El Colegio de México. Su publicación más reciente aparece en el libro Jóvenes y migraciones editado por Gedisa del cual también es coordinadora.

Dirección electrónica: andrea.btst@gmail.com

\section{Joachim Singelmann}

M.A. and Ph.D. degrees from the University of Texas at Austin. He has been on the faculties of Vanderbilt University (1974-1979); University of California-San Diego (1979-82); Universität Duisburg (1983-84); Louisiana State University (1987-2011); and the University of Texas at San Antonio (2011-present). His current position is Dean's Distinguished Professor of Public Policy at UTSA where he is also founding member of the Academy of Distinguished Researchers. His served as Population Affairs Officer in the Population Division of the United Nations (1980-86) and was chair at LSU and UTSA. He is a member of several professional associations had served as President of the Southern Demographic Association (1995-96) and the Rural Sociological Society (2009-10), and he edited the journal Rural Sociology (2005-08). He has published in the major sociology and demography journals in the United States, Europe, and Latin America, including AJS, Demography, Social Forces, Zeitschrift für Soziologie, Demographic Research, Acta Sociologica, British Journal of Sociology, European Sociological Review, and Revista Latinoamerica de Población. Among his books are From Agriculture to Services: The Transformation of Industrial Employment (1978); The End of Class Society? An Empirical Study of Social Structure and Class Consciousness in West Germany (coauthor, 1990); and Inequalities in Labor Market Areas (co-editor, 1993).

Dirección electrónica: Joachim.singelmann@utsa.edu

Artículo recibido el 3 de mayo de 2018 y aprobado el 24 de septiembre de 2018. 